\title{
KINETIKA DEGRADASI L-ASAM ASKORBAT PADA PROSES PASTEURISASI PUREE JAMBU BIJI (Psidium guajava) VARIETAS GETAS MERAH
}

\author{
KINETIC STUDY OF L-ASCORBIC ACID DEGRADATION ON GUAVA VAR. "GETAS \\ MERAH” (Psidium guajava) PUREE DURING PASTEURIZATION PROCESS
}

\author{
Bambang Sigit Amanto ${ }^{1}$, Dwi Ishartani ${ }^{1}$, Asiyatu Nurulaini ${ }^{1}$ \\ ${ }^{1)}$ Program Studi Ilmu dan Teknologi Pangan Fakultas Pertanian Universitas Sebelas Maret \\ Email: amantobambang@yahoo.co.id
}

\begin{abstract}
This study was aimed to determine kinetic of L-ascorbic acid degradation on guava puree during pasteurization process. This study used variation of temperature $\left(65,75\right.$ and $\left.85^{\circ} \mathrm{C}\right)$ and time pasteurization $(0,5$, 10, 15, 20, 25 and 30 minutes) with two replicates samples and duplo analysis of L-ascorbic acid content. Lascorbic acid content was analyzed using iodometric titration method. L-ascorbic acid data was processed to determine degradation kinetic, consist of $\mathrm{D}$ value, $\mathrm{z}$ value, $\mathrm{k}$ value dan Ea value.The result of this study showed that $\mathrm{D}$ value which expressed as the time required to achieve $90 \%$ of reduction in L-ascorbic acid concentration at 65,75 dan $85^{\circ} \mathrm{C}$ was 317,218 minutes, 166,884 minutes and 157,416 minutes, respectively. $\mathrm{z}$ value which expressed as the increase in temperature causing $90 \%$ reduction in $\mathrm{D}$ values was $65,703^{\circ} \mathrm{C}$. $\mathrm{k}$ value which expressed reaction rate constant at 65,75 dan $85^{\circ} \mathrm{C}$ was 0,00726 minutes $^{-1}, 0,0138$ minutes ${ }^{-1}$ and 0,01463 minutes $^{-1}$, respectively. Ea value which expressed minimum energy required to initiate a reaction was 35,517 $\mathrm{kJ} / \mathrm{gmol}$ or8,489 $\mathrm{kcal} / \mathrm{gmol}$.
\end{abstract}

Keywords: Guava puree, degradation kinetic, pasteurization, L-ascorbic acid

\section{ABSTRAK}

Tujuan dari penelitian ini adalah untuk menentukan kinetika degradasiL-asam askorbat pada proses pasteurisasi puree jambu biji. Penelitian dilakukan dengan variasi suhu $\left(65,75\right.$ dan $\left.85^{\circ} \mathrm{C}\right)$ dan waktu $(0,5,10$, 15, 20, 25 dan 30 menit) pasteurisasi dengan dua kali pengulangan sampel dan dua kali pengulangan analisa Lasam askorbat. Analisa L-asam askorbat menggunakan metode titrasi iodometri. Data analisa L-asam askorbat diolah untuk menentukan kinetika degradasi yang terdiri dari nilai D, nilai z, nilai k dan nilai Ea. Hasil penelitian menunjukkan bahwa nilai D sebagai waktu yang dibutuhkan untuk mengurangi 90\% konsentrasi L-asam askorbat pada suhu 65,75 dan $85^{\circ} \mathrm{C}$ berturut-turut sebesar 317,218 menit, 166,884 menit dan 157,416 menit. Nilai z yang menunjukkan kenaikan suhu yang menyebabkan pengurangan $90 \%$ nilai D sebesar $65,703^{\circ} \mathrm{C}$. Nilai $\mathrm{k}$ yang menunjukkan konstanta kecepatan reaksi pada suhu 65,75 dan $85^{\circ} \mathrm{C}$ berturut-turut sebesar 0,00726 menit $^{-1}, 0,0138$ menit $^{-1}$ dan 0,01463 menit $^{-1}$. Nilai Ea yang menunjukkan energi minimum yang dibutuhkan untuk memulai reaksi sebesar35,517 kJ/gmol atau 8,489 kcal/gmol.

Kata kunci: Puree jambu biji, kinetika degradasi, pasteurisasi, L-asam askorbat

\section{PENDAHULUAN}

Jambu biji dikenal memiliki kandungan vitamin $\mathrm{C}$ atau L-asam askorbat yang lebih tinggi dibanding buah lainnya. Kandungan Lasam askorbat dapat bervariasi dari 60-1.000 mg/100 gram jambu biji segar. Perbedaan kandungan tersebut dipengaruhi oleh beberapa faktor, diantaranya varietas jambu biji, lingkungan, cara penanaman, tingkat kematangan dan penangananpasca panen
(Mitra, 1997 dalam Rueda, 2005). Manfaat L-asam askorbat bagi tubuh sangat banyak, diantaranya dapat mencegah penyakit scurvy dan dapat berfungsi sebagai antioksidan dalam tubuh manusia.

Menurut Badan Pusat Statistik (2013), produksi jambu biji pada tahun 2012 menduduki peringkat 15 dari 27 produksi buah-buahan tahunan Indonesia, yaitu sebesar 208.551 ton. Jumlah produksi tersebutmasih terbilang rendah dikarenakan variasi produk olahannya yang masih 
terbatas. Oleh karenanya diperlukan usaha diversifikasi untuk meningkatkan nilai produksi serta ekonomi jambu biji. Pengolahan buah jambu biji menjadi puree memiliki keuntungan, terutama mengatasi sifat jambu biji yang memiliki umur simpan yang singkat atau mudah busuk. Selain meningkatkan nilai ekonomis dan daya simpan produk, pengolahan menjadi puree juga dapat memudahkan distribusi, mempertahankan nilai gizi dan cita rasa serta mengurangi pemakaian flavor sintetis(Rahmawati dkk, 2003 dalam Ratna dkk, 2008). Puree selanjutnya dapat digunakan sebagai bahan dasar atau bahan tambahan dalam produksi nektar, jus, selai dan jelli (Hui, 2006).

Untuk menghindari kerusakan mikrobiologis dan enzimatis, dilakukan pemberian panas ringan (pasteurisasi) terhadap puree. Namun, proses pasteurisasi tersebut dapat mempengaruhi nilai gizi puree. Salah satu kandungan gizi yang mudah rusak dalam proses pasteurisasi puree jambu biji adalah L-asam askorbat karena mudah teroksidasi, serta proses oksidasi tersebut dapat dipercepat dengan adanya panas, sinar, suasana alkali, enzim, oksidator dan katalis logam (Winarno, 2004). Pada penelitian Mayer (2007) yang mempelajari pasteurisasi jus jeruk, menunjukkan terjadinya penurunan asam askorbat hingga $21,4 \pm 0,7 \%$ dan penurunan $\beta$-karoten hingga $36,5 \pm 2 \%$.

L-asam askorbat merupakan salah satu komponen gizi yang diunggulkan pada produk olahan jambu biji, sehingga kandungannya harus dipertahankan selama pengolahan. Oleh karenanya, pasteurisasi puree jambu biji harus dilakukan dengan kombinasi waktu dan suhu yang tepat sehingga cukup untuk membunuh mikroba patogen namun dapat mempertahankan kandungan L-asam askorbat. Maka perlu dilakukan pendekatan studi mengenai kinetika degradasi puree jambu biji.

Penelitian ini bertujuan untuk menentukan kinetika degradasi L-asam askorbat puree jambu biji saat proses pasteurisasi meliputi parameter nilai $\mathrm{D}$, nilai z, nilai k dan nilai Ea.

\section{METODE PENELITIAN}

\section{Bahan dan Alat}

Bahan yang digunakan adalah jambu biji organik varietas getas merah berbiji sedikit (dipanen pada bulan Oktober dari Lembah Hijau Multifarm di desa Triyagan, Mojolaban, Sukoharjo), aquades dan asam sitrat. Sedangkan untuk pengujian kadar Lasam askorbat menggunakan aquades, larutan iodin $0,01 \mathrm{~N}$ dan amilum $1 \%$.

Alatyang digunakan dalam pembuatan puree jambu biji adalah waterbath, termometer, stopwatch, blender, saringan, icebath dan alat-alat gelas. Sedangkan alat yang digunakan dalam analisis kadar L-asam askorbat adalah buret, magnetic stirrer, alatalat gelas, alumunium foil, kain dan kertas saring.

\section{Tahapan Penelitian}

Pembuatan puree jambu biji diawali dengan menyortasi jambu biji berdasarkan kematangan yang sama. Buah dicuci, dikupas dan dipotong kecil agar memudahkan saat penghancuran dengan blender. Saat diblender, ditambahkan aquades sebanyak 1/4 dari massa buah. Setelah hancur, bubur jambu biji kemudian disaring untuk memisahkan bijinya. Selanjutnya ditambahkan asam sitrat $0,3 \% \mathrm{~b} / \mathrm{b}$ dan diaduk rata (Ratna dkk, 2008). Bubur jambu biji kemudian dimasukkan ke dalam botol kaca dan dipasteurisasi sesuai dengan perlakuan suhu $\left(65^{\circ} \mathrm{C}, 75^{\circ} \mathrm{C}\right.$, dan $\left.85^{\circ} \mathrm{C}\right)$ dan waktu $(0,5$, $10,15,20,25$ dan 30 menit) sambil diaduk selama prosesnya.

\section{Rancangan Penelitian}

Percobaan dilakukan dengan 3 suhu pasteurisasi yaitu $65^{\circ} \mathrm{C}, 75^{\circ} \mathrm{C}$, dan $85^{\circ} \mathrm{C}$ serta 7 waktu pasteurisasi yaitu $0,5,10,15,20,25$ dan 30 menit. Pengulangan sampel dilakukan sebanyak dua kali dan pengulangan analisa dilakukan sebanyak dua kali. Data yang diperoleh kemudian diolah dengan Microsoft Excel 2007 untuk mencari kinetika degradasi 
L-asam askorbat yang terdiri dari nilai D, nilai $\mathrm{z}$, nilai $\mathrm{k}$ dan nilai $\mathrm{Ea}$.

\section{Metode Analisis}

Analisa L-asam askorbat puree jambu biji menggunakan metode titrasi iodometri (Sudarmadji dkk, 1997).

\section{Penentuan Kinetika Degradasi}

Pemodelan kinetika degradasi L-asam askorbat biasanya diasumsikan mengikuti kinetika orde satu dalam bahan biologis sistem makanan (Johnson dkk, 1995 dalam Jiang dkk, 2012). Persamaan orde satu adalah:

$\ln \left(\frac{c}{c_{0}}\right)=-k t$. .(Persamaan 1)

Sedangkan penentuan nilai $\mathrm{D}$, nilai $\mathrm{z}$, nilai $\mathrm{k}$ dan nilai Ea menggunakan persamaan sebagai berikut:

$$
\begin{aligned}
& \mathrm{D}=\frac{\mathrm{t}}{\log \mathrm{C}_{\mathrm{b}}-\log \mathrm{C}} \ldots \ldots \ldots \ldots \ldots \ldots \ldots \ldots . .(\text { Persamaan } 2) \\
& \mathrm{z}=\frac{\mathrm{T}_{2}-\mathrm{T}_{1}}{\log \mathrm{D}_{1}-\log \mathrm{D}_{2}} \ldots \ldots \ldots \ldots \ldots \ldots \ldots . . . . . . . . .(\text { Persamaan } 3)
\end{aligned}
$$

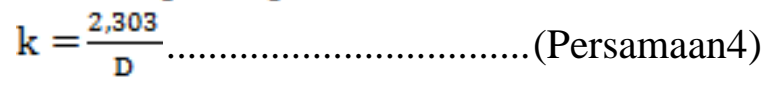

$$
\begin{aligned}
& k=k_{0} \cdot e^{-\left(\frac{E_{a}}{R T}\right)} \\
& \text { Keterangan: } \\
& \text { Co }=\text { konsentrasi awal (mg) } \\
& \mathrm{C}=\text { konsentrasi setelah proses (mg) } \\
& \mathrm{k}=\text { konstanta laju reaksi (menit-1) } \\
& \mathrm{t}=\text { waktu proses (menit) } \\
& \mathrm{D}=\text { decimal reduction time (menit) } \\
& \mathrm{Z}=\text { thermal resistance constant }(\mathrm{K}) \\
& \mathrm{T}=\text { suhu proses }(\mathrm{K}) \\
& \mathrm{D} 1 \text { = nilai } \mathrm{D} \text { pada suhu T1 (menit) } \\
& \mathrm{D} 2 \text { = nilai } \mathrm{D} \text { pada suhu } \mathrm{T} 2 \text { (menit) } \\
& \mathrm{k} 0 \text { = faktor preeksponensial (menit-1) } \\
& \mathrm{R}=\text { tetapan gas } \\
& (8,314 \mathrm{j} / \mathrm{mol} . \mathrm{K} / 1,987 \mathrm{cal} / \mathrm{mol} . \mathrm{K})
\end{aligned}
$$$$
\text { (Sun, 2006) }
$$

\section{HASIL DAN PEMBAHASAN}

\section{A. Kadar L-Asam Askorbat Puree Jambu Biji Setelah Proses Pasteurisasi}

L-asam askorbat adalah vitamin larut air yang sangat dibutuhkan oleh tubuh. Istilah L-asam askorbat merupakan nama trivial dari 2,3didehidro-L-treo-hexano-1,4-lakton yang juga dikenal sebagai asam hexuron. Lasam askorbat merupakan agen pereduksi yang kuat, L-asam askorbat teroksidasi dengan mudah menjadi asam dehidro-Laskorbat melalui intermediet radikal asam semidehidro-L-askorbat (terkadang disebut juga asam monodehidro askorbat). Ketiga bentuk L-asam askorbat tersebut membentuk sistem redoks yang reversibel (Combs, 2008).

Sedangkan pada oksidasi L-asam askorbat yang dikatalis logam, kompleks yang terjadi akan memisah dan membentuk asam dehidro-L-askorbat, hidrogen peroksida dan ion logam. Asam dehidro-L-askorbat mudah terhidrolisis menjadi asam 2,3 diketogulonat yang irreversibel dan tidak memiliki aktivitas asam askorbat. $\mathrm{pH}$ makanan sangat mempengaruhi stabilitas L-asam askorbat. Pencoklatan pada produk makanan juga sangat mengurangi kadar L-asam askorbat (Eitenmiller dan Landen, 1999). Senyawa asam 2,3 diketogulonat kemudian terdekomposisi menjadi furfural yang membentuk pigmen warna coklat dan melepaskan $\mathrm{CO}_{2}$ (Tranggono dan Sutardi, 1990 dalam Kusuma dkk, 2007).

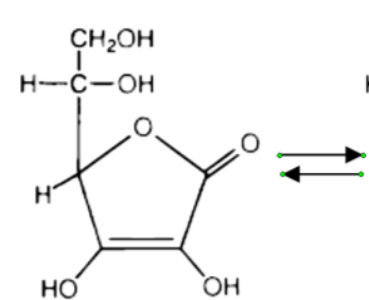

(a)

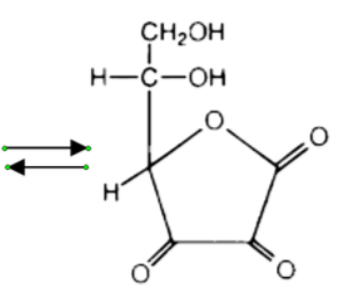

(b)

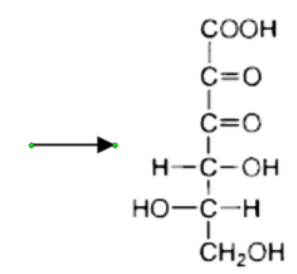

(c)
Gambar 1. Struktur Asam Askorbat dalam Bentuk L-Asam Askorbat (a), Asam dehidro-L-askorbat (b) dan Asam Diketogulonat (c)

Saat berada dalam bentuk L-asam askorbat, keaktifannya 100\%. Namun, saat menjadi bentuk asam dehidro-Laskorbat, keaktifannya menurun menjadi 80\% (Combs, 2008). Setelah melalui proses pasteurisasi, kadar dan retensi Lasam askorbat dalam puree jambu biji dapat dilihat pada Tabel 1. 
Kadar L-asam askorbat awal adalah $169,5829 \mathrm{mg} / 100$ gram. Retensi L-asam askorbat pada pasteurisasi dengan suhu $65^{\circ} \mathrm{C}$ selama 30 menit sebesar $81,5356 \%$ dari $169,5829 \mathrm{mg} / 100$ gram menjadi $138,2705 \mathrm{mg} / 100$ gram. Retensi L-asam askorbat pada pasteurisasi dengan suhu $75^{\circ} \mathrm{C}$ selama 30 menit sebesar $65,3623 \%$ dari $169,5829 \mathrm{mg} / 100$ gram menjadi $110,8433 \mathrm{mg} / 100$ gram. Retensi L-asam askorbat pada pasteurisasi dengan suhu $85^{\circ} \mathrm{C}$ selama 30 menit sebesar $61,8799 \%$ dari $169,5829 \mathrm{mg} / 100$ gram menjadi $104,9377 \mathrm{mg} / 100$ gram.

Tabel 1. Kadar L-Asam Askorbat pada Puree Jambu Biji Setelah Pasteurisasi

\begin{tabular}{cccc}
\hline $\begin{array}{c}\text { Suhu } \\
\left({ }^{\circ} \mathrm{C}\right)\end{array}$ & $\begin{array}{c}\text { Waktu } \\
(\text { menit })\end{array}$ & $\begin{array}{c}\text { Kadar L-Asam } \\
\text { Askorbat } \\
(\mathrm{mg} / 100 \text { gram })\end{array}$ & $\begin{array}{c}\text { Retensi L-Asam } \\
\text { Askorbat } \\
(\%)\end{array}$ \\
\hline 65 & 0 & 169,5829 & 100 \\
& 5 & 169,2213 & $\mathbf{B}$. \\
& 10 & 165,6548 & 97,7868 \\
& 15 & 155,8777 & 91,6837 \\
& 20 & 147,3806 & 86,9077 \\
& 25 & 146,5803 & 86,4358 \\
75 & 30 & 138,2705 & 81,5356 \\
& 0 & 169,5829 & 100 \\
& 5 & 144,2366 & 85,0537 \\
& 10 & 131,7295 & 77,6786 \\
& 15 & 120,5325 & 71,0759 \\
& 20 & 112,5980 & 66,3970 \\
& 25 & 112,3301 & 66,2391 \\
85 & 30 & 110,8433 & 65,3623 \\
& 0 & 169,5829 & 100 \\
& 5 & 140,1493 & 82,6435 \\
& 10 & 132,3365 & 78,0365 \\
& 15 & 123,5779 & 72,8717 \\
& 20 & 114,3144 & 67,4092 \\
& 25 & 111,2585 & 65,6071 \\
& 30 & 104,9377 & 61,8799 \\
\hline
\end{tabular}

Penurunan kadar L-asam askorbat terbesar terjadi pada suhu $85^{\circ} \mathrm{C}$ dan penurunan kadar L-asam askorbat terkecil terjadi pada suhu $65^{\circ} \mathrm{C}$. Pada masing-masing suhu, kadar L-asam askorbat semakin berkurang di setiap penambahan waktu. Hal tersebut dikarenakan oksidasi L-asam askorbat dapat dipercepat dengan adanya panas yang berasal dari suhu dan akumulasi selama pasteurisasi (Winarno, 2004).
Sehingga semakin tinggi suhu dan semakin lama proses pasteurisasi maka semakin rendah retensiL-asam askorbat dalam puree jambu biji. Penurunan kadar L-asam askorbat setelah pasteurisasi juga terjadi pada penelitian Kusuma dkk (2007) yang melakukan pasteurisasi jus jeruk selama 4,5 menit dengan suhu 70, 80 dan $90^{\circ} \mathrm{C}$. Kadar L-asam askorbat pada pasteurisasi suhu $70^{\circ} \mathrm{C}$ berkurang $8,29 \%$, pada pasteurisasi suhu $80^{\circ} \mathrm{C}$ berkurang $10,17 \%$ dan pada pasteurisasi suhu $90^{\circ} \mathrm{C}$ berkurang $12,04 \%$. Maka retensi L-asam askorbat pada penelitian lebih besar dibandingkan penelitian Kusuma dkk (2007). Hal tersebut menunjukkan bahwa L-asam askorbat dalam puree jambu biji lebih sensitif terhadap panas dibandingkan L-asam askorbat dalam jus jeruk.

\section{B. Penentuan Kinetika Degradasi L-Asam Askorbat Puree Jambu Biji pada Saat Proses Pasteurisasi}

Pemodelan kinetika orde satu degradasi L-asam askorbat menggunakan (Persamaan 1) dapat dilakukan dengan membuat plot antara waktu (sumbu $\mathrm{x}$ ) dan ln kadar L-asam askorbat (sumbu y) pada masing-masing suhu (Sukasih dkk, 2005). Berdasarkan Gambar 2, didapatkan nilai $\mathrm{R}^{2}$ suhu 65,75 dan $85^{\circ} \mathrm{C}$ berturut-turut sebesar 0,$95059 ; 0,87829$ dan 0,93245. Nilai $\mathrm{R}^{2}$ (koefisien determinasi) menunjukkan proporsi keragaman total nilai-nilai peubah y yang dapat dijelaskan oleh nilai-nilai peubah $\mathrm{x}$ melalui hubungan persamaan linier. Jika didapat $\mathrm{R}^{2}=1$ bermakna bahwa $100 \%$ di antara keragaman total nilai-nilai y dalam contoh dapat dijelaskan secara sempurna oleh hubungan persamaan liniernya dengan nilai-nilai $\mathrm{x}$ (Walpole, 1995). nilai $\mathrm{R}^{2}$ dapat digunakan sebagai penunjuk kevalidan sebuah regresi linier.

Penelitian Ariahu dan Abashi (2011) tentang degradasi L-asam askorbat daun labu rambat juga mengikuti orde satu dengan nilai $\mathrm{R}^{2}$ antara $0,882-0,974$. 


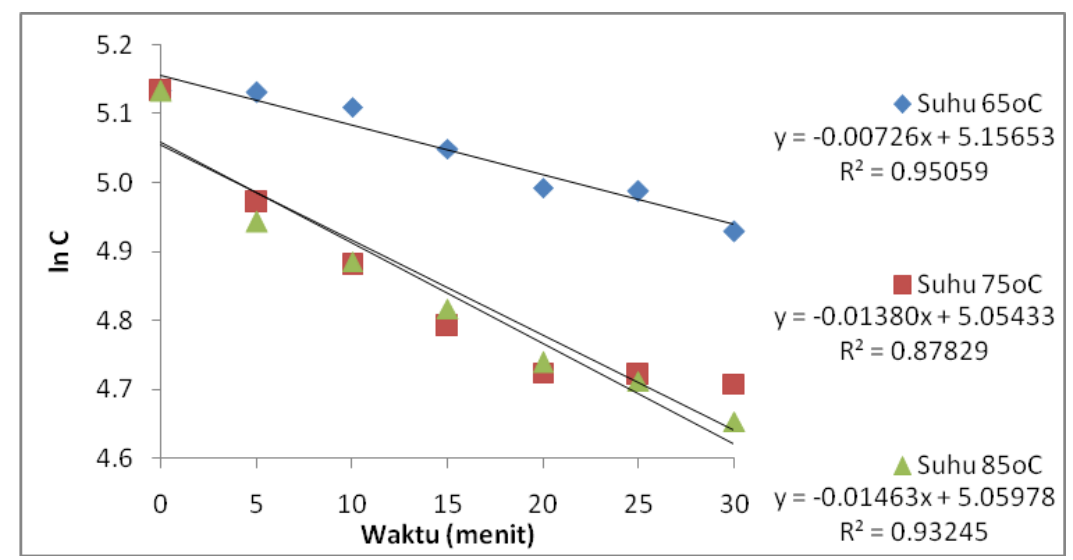

Gambar 2. Kurva Orde Reaksi 1 menggunakan (Persamaan 1)pada Suhu 65, 75 dan $85^{\circ} \mathrm{C}$

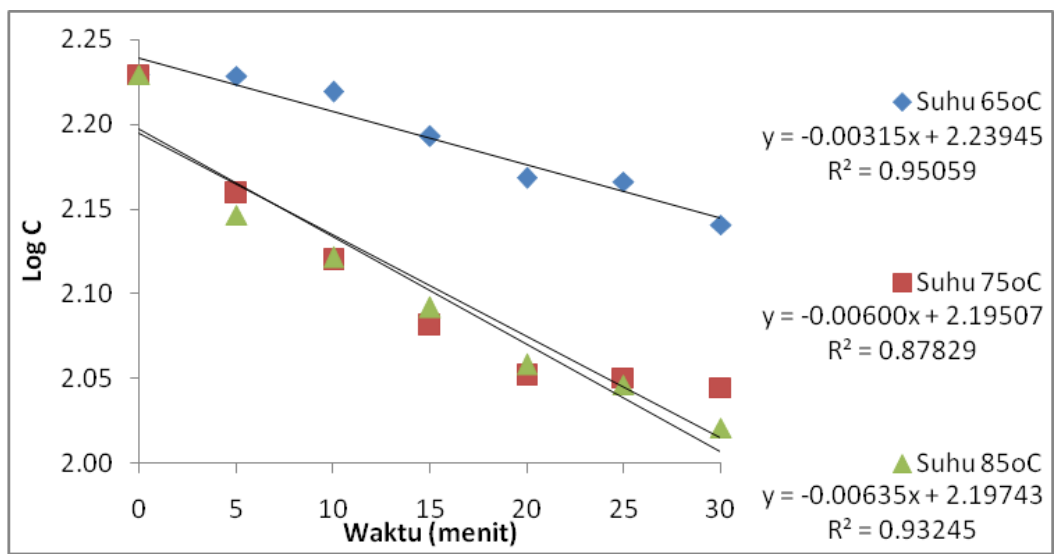

Gambar 3. Kurva (Persamaan 2) pada Suhu 65, 75 dan $85^{\circ} \mathrm{C}$ untuk Menentukan Nilai D

Nilai R2 degradasi L-asam askorbat puree jambu biji lebih rendah dibanding $\mathrm{R} 2$ degradasi Lasam askorbat daun labu rambat. Hal tersebut menunjukkan bahwa kevalidan regresi (Persamaan 1) pada daun labu rambat lebih tinggi dibanding kevalidan hasil regresi (Persamaan 1) pada puree jambu biji.

\section{Penentuan Decimal Reduction Time}

Decimal reduction time atau nilai $\mathrm{D}$ adalah waktu yang diperlukan untuk menurunkan kadar L-asam askorbat sebesar satu siklus log atau 90\% dari kadar awal. Penentuan nilai D dapat menggunakan dilakukan dengan membuat plot antara waktu pasteurisasi (sumbu x) dengan log kadarL-asam askorbat (sumbu y) mengikuti (Persamaan 2). Nilai D merupakan [-1/slope] dari kurva persamaan tersebut (Sukasih dkk, 2005).

Melalui Gambar 3 dapat ditentukan nilai $\mathrm{D}$ pada suhu $65^{\circ} \mathrm{C}$ $\left(\mathrm{D}_{65^{\circ}} \mathrm{C}\right)$, nilai $\mathrm{D}$ pada suhu $75^{\circ} \mathrm{C}$ $\left(\mathrm{D}_{75^{\circ}} \mathrm{C}\right)$ dan nilai $\mathrm{D}$ pada suhu $85^{\circ} \mathrm{C}$ $\left(\mathrm{D}_{85}{ }^{\circ} \mathrm{C}\right)$ masing-masing sebesar 317,4603 menit, 166,6667 menit dan 157,4803 menit. Urutan nilai D yang terbesar adalah nilai $\mathrm{D}_{650 \mathrm{o}}$, kemudian $\mathrm{D}_{750 \mathrm{oC}}$ dan yang terkecil adalah nilai D85oc. Jadi semakin tinggi suhu dan semakin lama pasteurisasi, maka semakin besar nilai slope yang ditunjukkan pada kurva dan semakin kecil nilai D. Artinya semakin kecil nilai D, makaL-asam askorbat semakin mudah terdegradasi karena perlakuan panas pada suhu tersebut.

Penelitian Castro dkk (2004) tentang degradasi pulp arbei didapat nilai $\mathrm{D}_{750 \mathrm{o}}$ degradasi L-asam askorbat 
sebesar 175 menit. Nilai $D_{750 c}$ puree jambu biji lebih rendah dibanding dibanding $\mathrm{D}_{750 \mathrm{o}}$ pulp arbei. Hal tersebut menunjukkan bahwa pada suhu $75^{\circ} \mathrm{C}, \quad$ L-asam askorbat pada puree jambu biji membutuhkan waktu yang lebih cepat untuk terdegradasi sebesar satu siklus log dibanding pulp arbei.

\section{Penentuan Thermal Resistance Constant}

Thermal resistance constant atau nilai $\mathrm{z}$ adalah perubahan suhu yang diperlukan untuk menurunkan nilai D sebesar satu siklus log atau 90\% dari nilai awal. Penentan nilai z mengikuti (Persamaan 3) atau dengan plot antara suhu pasteurisasi (sumbu $\mathrm{x}$ ) dengan log nilai $\mathrm{D}$ (sumbu y) pada kurva linier. Nilai z merupakan [1/slope] dari kurva persamaan tersebut (Sukasih dkk, 2005).

Berdasarkan Gambar 4, diperoleh persamaan regresiy=$0,01522 x+3,44809 \quad$ dengan $\mathrm{R}^{2}=0,81205$. Sehingga didapat nilai $\mathrm{z}$ sebesar $65,703^{\circ} \mathrm{C}$. Hal tersebut menunjukkan bahwa diperlukan kenaikan suhu hingga $65,703^{\circ} \mathrm{C}$ agar nilai $\mathrm{D}$ berkurang sebesar satu siklus log. Artinya semakin tinggi nilai $\mathrm{z}$, maka penurunan nilai $\mathrm{D}$ semakin lama sehingga L-asam askorbat tidak mudah terdegradasi atau ketahananLasam askorbat terhadap panas lebih tinggi.

Pada penelitian Karhan dkk (2004) tentang degradasi L-asam askorbat pulp rose hip dengan $\mathrm{pH}$ $3,85 \pm 0,08$ didapat nilai $\mathrm{z}$ sebesar $53^{\circ} \mathrm{C}$. Pada penelitian Castro dkk (2004) tentang degradasi pulp arbei dengan $\mathrm{pH} 4$ didapat nilai z sebesar $46,73^{\circ} \mathrm{C}$. Pada penelitian Jobe (2003) tentang degradasi L-asam askorbat kentang kaleng dengan $\mathrm{pH} \leq 4,5$ didapat nilai $\mathrm{z}$ sebesar $44^{\circ} \mathrm{C}$. Dan pada penelitian Mayer dkk (2007) tentang degradasi L-asam askorbat jus jeruk dengan $\mathrm{pH} 3,6 \pm 0,06$ didapat nilai z sebesar $64 \pm 0,6^{\circ} \mathrm{C}$.

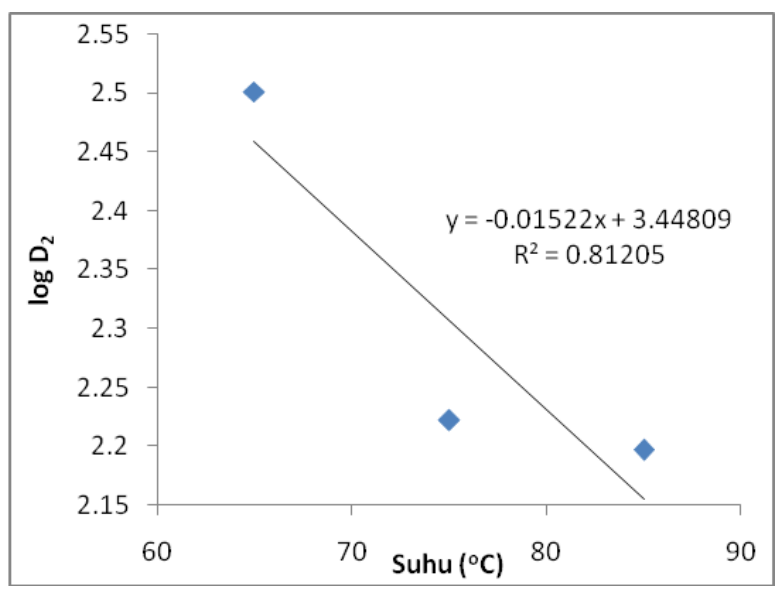

Gambar4. Kurva (Persamaan 3) untuk Menentukan Nilai z

Puree jambu biji pada penelitian memiliki $\mathrm{pH}$ 3,66 sehingga hampir sama dengan $\mathrm{pH}$ jus jeruk dan lebih rendah dibanding $\mathrm{pH}$ pulp rose hip, pulp arbei dan kentang kaleng. Sehingga nilai $\mathrm{z}$ puree jambu tidak berbeda jauh dengan nilai $\mathrm{z}$ jus jeruk. Namun nilai z puree jambu biji lebih tinggi dibanding nilai pulp rose hip, pulp arbei dan kentang kaleng. Sehingga disimpulkan bahwa semakin rendah $\mathrm{pH}$ maka nilai $\mathrm{z}$ semakin tinggi. Artinya semakin rendah $\mathrm{pH}$ maka L-asam askorbat semakin tahan terhadap perlakuan panas. Hal tersebut dikarenakan pada $\mathrm{pH}$ lebih rendah, L-asam askorbat lebih stabil. Stabilitas L-asam askorbat lebih tinggi pada $\mathrm{pH}$ antara 3-4,5 dibanding pada $\mathrm{pH}$ antara 5-7 (Ball, 2006).

\section{Penentuan Reaction Rate Constant}

Reaction rate constant atau nilai $\mathrm{k}$ adalah konstanta kecepatan reaksi. Nilai k dapat ditentukan ditentukan dengan membuat kurva (Persamaan 1) yaitu plot antara waktu (t) dan ln kadar L-asam askorbat $(\ln \mathrm{C})$ dimana nilai $\mathrm{k}$ merupakan |-slope| dari kurva tersebut. Nilai k juga dapat ditentukan dengan (Persamaan 4) (Sun, 2006). 
Hasil penentuan nilai $\mathrm{k}$ berdasarkan (Persamaan 4) dapat dilihat pada Tabel 2.Nilai k degradasi L-asam askorbat yang di dapat pada suhu 65,75 dan $85^{\circ} \mathrm{C}$ masing-masing sebesar 0,00726 menit ${ }^{-1}, 0,0138$ menit $^{-}$ ${ }^{1}$ dan 0,01463 menit $^{-1}$. Urutan nilai $\mathrm{k}$ yang terbesar adalah pada suhu $85^{\circ} \mathrm{C}$, kemudian pada suhu $75^{\circ} \mathrm{C}$ dan yang terkecil pada suhu $65^{\circ} \mathrm{C}$. Hal tersebut menunjukkan bahwa semakin besar suhu pasteurisasi, maka semakin besar nilai k. Artinya semakin besar k maka kecepatan degradasi L-asam askorbat pada suhu tersebut semakin cepat sehingga retensiL-asam askorbat semakin kecil. Atau semakin kecil nilai D maka semakin besar nilai k. Artinya semakin cepat penurunan kadar L-asam askorbat sebesar satu siklus log menunjukkan bahwa kecepatan degradasi L-asam askorbat semakin besar.

Tabel 2.Nilai D dan Nilai k

\begin{tabular}{|c|c|c|}
\hline Suhu $\left(^{\circ}\right.$ & ilai D (mer & ai k (me \\
\hline 65 & 317,4603 & 0,00726 \\
\hline 75 & 166,6667 & 0,0138 \\
\hline 85 & 157,4803 & 0,01463 \\
\hline
\end{tabular}

Pada penelitian Vikram dkk (2005), didapat nilai $\mathrm{k}$ degradasi Lasam askorbat pada pulp rose hip suhu $75^{\circ} \mathrm{C}$ sebesar 0,0852 menit $^{-1}$. Nilai k puree jambu biji pada suhu $75^{\circ} \mathrm{C}$ lebih kecil dibanding pulp rose hip. Hal tersebut menunjukkan bahwa kecepatan degradasi L-asam askorbat puree jambu biji berlangsung lambat atau nilai D lebih besar sehingga retensi L-asam askorbat lebih besar dibanding pulp rose hip.

\section{Penentuan Activation Energy}

Activation energy atau nilai Ea adalah energi minimum yang dibutuhkan untuk memulai reaksi degradasi L-asam askorbat. Penentuan nilai Ea menggunakan (Persamaan 5) dengan membuat plot antara 1/suhu (sumbu $\mathrm{x}$ ) dengan ln konstanta laju reaksi (sumbu y). Nilai Ea merupakan hasil perkalian [-slope] dari kurva persamaan tersebut dengan tetapan $\mathrm{R}$ $(8,314 \mathrm{~J} / \mathrm{mol} . \mathrm{K}$ atau $1,987 \mathrm{cal} / \mathrm{mol} . \mathrm{K})$ (Sukasih dkk, 2005).

Berdasarkan

Gambar

5 , diperoleh persamaan regresi $\mathrm{y}=-$ $4272 x+7.8049$ dengan $\mathrm{R}^{2}=0.8248$. Sehingga didapat nilai Ea degradasi L-asam askorbat sebesar 35,5174 $\mathrm{kJ} / \mathrm{mol}$ atau $8,4885 \mathrm{kcal} / \mathrm{mol}$. Hal tersebut menunjukkan bahwa dibutuhkan energi minimal 35,5174 $\mathrm{kJ}$ untuk memulai reaksi degradasi Lasam askorbat.

Pada literatur lain, degradasi Lasam askorbat beberapa variasi jus jeruk yang dipasteurisasi dengan suhu yang sama $\left(20-96^{\circ} \mathrm{C}\right)$ didapatkan nilai Ea antara $21-53 \mathrm{~kJ} / \mathrm{mol}$ dan nilai $\mathrm{z}$ antara $36-118^{\circ} \mathrm{C}$. Faktor yang mempengaruhi lebarnya kisaran nilai Ea dan $\mathrm{z}$ adalah karakteristik intrinsik produk seperti varietas dan kematangan, $\mathrm{pH}$ dan tingkat oksigen terlarut (Mayer dkk, 2007).

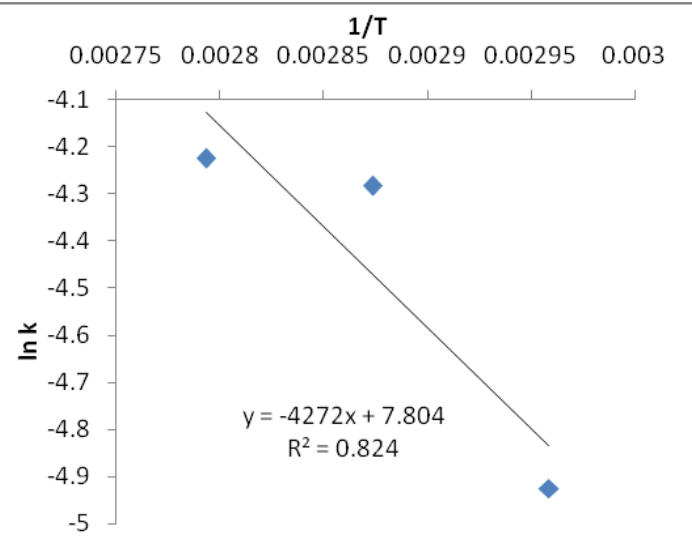

Gambar 5. Kurva (Persamaan 5) untuk Menentukan Nilai Ea

Pada penelitian Jobe (2003) didapat nilai $\mathrm{Ea}$ kentang kaleng sebesar $56 \mathrm{~kJ} / \mathrm{mol}$. Pada penelitian Karhan dkk (2004) didapat nilai Ea pulp rose hip sebesar $47,5 \mathrm{~kJ} / \mathrm{mol}$. Pada penelitian Vikram dkk (2005) didapat nilai Ea jus jeruk sebesar 
39,84 $\pm 0,61 \mathrm{~kJ} / \mathrm{mol}$. Dan pada penelitian Mayer dkk (2007) didapat nilai Ea jus jeruk $\mathrm{pH} 3,6 \pm 0,06$ sebesar $35,9 \pm 0,5 \mathrm{~kJ} / \mathrm{mol}$. Maka nilai Ea puree jambu biji hampir sama dengan kedua jenis jus jeruk $\mathrm{pH} 3,6 \pm 0,06$ dan lebih rendah dibanding kentang kaleng, pulp rose hip dan jus jeruk. Semakin rendahnya nilai $\mathrm{Ea}$ menunjukkan bahwa reaksi degradasi L-asam askorbat akan cepat dimulai.

\section{KESIMPULAN}

1. Nilai D yang menunjukkan waktu yang dibutuhkan untuk mengurangi 90\% konsentrasi L-asam askorbat pada suhu $65^{\circ} \mathrm{C}, 75^{\circ} \mathrm{C}$ dan $85^{\circ} \mathrm{C}$, berturut-turut sebesar 317,218 menit, 166,884 menit dan 157,416 menit.

2. Nilai z yang menunjukkan kenaikan suhu yang menyebabkan pengurangan $90 \%$ nilai D, yaitu sebesar $65,703^{\circ} \mathrm{C}$.

3. Nilai $\mathrm{k}$ yang menunjukkan konstanta kecepatan reaksi pada suhu $65^{\circ} \mathrm{C}, 75^{\circ} \mathrm{C}$ dan $85^{\circ} \mathrm{C}$, berturut-turut sebesar 0,00726 menit $^{-1}, \quad 0,0138$ menit $^{-1}$ dan 0,01463 menit $^{-1}$.

4. Nilai Ea yang menunjukkan energi minimum yang dibutuhkan untuk memulai reaksi, yaitu sebesar 35,517 $\mathrm{kJ} / \mathrm{gmol}$ atau $8,489 \mathrm{kcal} / \mathrm{gmol}$.

\section{DAFTAR PUSTAKA}

Ariahu, C. C. dan Abashi, D. K. 2011. Kinetics of Ascorbic Acid Loss During Hot Water Blanching of Fluted Pumpkin (Telfairia occidentalis) Leaves. Journal of Food Science Technology, Vol. 48, No. 4.

Badan Pusat Statistik. 2013. Perkembangan Beberapa Indikator Utama SosialEkonomi Indonesia Agustus 2013. Badan Pusat Statistik. Jakarta.

Ball, G. F. M. 2006. Vitamins in Foods: Analysis, Bioavailability and Stability. CRC Press. Boca Raton.
Castro, I., Teixeira, J. A., Salengke, S., Sastry, S. K. dan Vicentea, A. A. 2004. Ohmic Heating of Strawberry Products: Electrical Conductivity Measurements and Ascorbic Acid Degradation Kinetics. Innovative Food Science and Emerging Technologies, Vol. 5.

Combs, G. F. 2008. The Vitamins Fundamental Aspects in Nutrition and Health. Elsevier Academic Press. New York.

Eitenmiller, R. R. dan Landen, W. O. 1999. Vitamin Analysis for the Health and Food Sciences. CRC Press. Boca Raton.

Hui, Y. H. 2006. Handbook of Fruits and Fruit Processing. Blackwell Publising. Oxford.

Jobe, B. 2003. Heating Behavior and Quality Factor Retention in Canned Potatoes as Influenced bv Process Variables During Endover-End Rot Ational Processing. Tesis. Departemen Ilmu Pangan dan Kimia Pertanian, Universitas McGill. Quebec.

Johnson, J.R., Braddock, R.J. dan Chen, C.S. 1995. Kinetics of Ascorbic Acid Loss and Non-Enzymatic Browning in Orange Juice Serum: Experimental Rate Constants. Dalam: Jiang, L., Zheng, H. dan $\mathrm{Lu}, \mathrm{H}$. Use of Linear and Weibull Functions to Model Ascorbic Acid Degradation in Chinese Winter Jujube During Postharvest Storage in Light and Dark Conditions. Journal of Food Processing and Preservation.

Karhan, M., Aksu, M., Tetik, N. dan Turhan, I. 2004. Kinetic Modeling of Anaerobic Thermal Degradation of Ascorbic Acid in Rose Hip (Rosa canina L) Pulp. Journal of Food Quality, Vol. 27.

Kusuma,H. R., Ingewati, T., Indraswati, N. dan Martina. 2007. Pengaruh Pasteurisasi Terhadap Kualitas Jus Jeruk Pacitan. Widya Teknik, Vol. 6, No. 2.

Mayer, C. D., Tbatou, M., Carail, M., Veyrat, C.C., Dornier, M. dan Amiot, M. J. 
2007. Thermal Degradation of Antioxidant Micronutrients in Citrus Juice: Kinetics and Newly Formed Compounds. Journal of Agriculture and Food Chemistry, Vol. 55, No. 10.

Mitra, S. 2007. Postharvest Physiology and Storage of Tropical and Subtropical Fruits. Dalam: Rueda, F. D. M. N. 2005. Guava (Psidium guajava L.) Fruit Phytochemicals, Antioxidant Properties and Overall Quality as Influenced by Postharvest Treatments. Tesis. University of Florida.

Rahmawati, Kusumadewi, E. dan Somali, L. 2003. Pengaruh Jenis Pengemas dan Lama Penyimpanan Terhadap Mutu Puree Pisang. Dalam: Ratna, Y., Rosida dan Kusuma, L. 2008. Pembuatan Puree Jambu Biji Merah (Kajian Konsentrasi Asam Sitrat dan Lama, Penyimpanan pada Suhu Kamar). Reka Pangan: Jurnal Teknologi Pangan, Vol. 2 No. 2.

Ratna, Y., Rosida dan Kusuma, L. 2008. Pembuatan Puree Jambu Biji Merah (Kajian Konsentrasi Asam Sitrat dan Lama, Penyimpanan pada Suhu Kamar). Reka Pangan: Jurnal Teknologi Pangan, Vol. 2 No. 2.

Sudarmadji, S., Haryono, B. dan Suhardi. 1997. Prosedur Analisa untuk Bahan Makanan dan Pertanian. Liberty. Yogyakarta.

Sukasih, E., Setyadjit dan Hariyadi, R. D. 2005. Analisis Kecukupan Panas Pada Proses Pasteurisasi Puree Mangga (Mangifera indica L).Jurnal Pascapanen, Vol. 2,No. 2.

Sun, D. W. 2006. Thermal Food Processing : New Technologies and Quality Issues. CRC Press. Boca Raton.

Tranggono dan Sutardi. 1990. Biokimia dan Teknologi Pasca Panen. Dalam Kusuma,H. R., Ingewati, T., Indraswati, N. dan Martina. 2007. Pengaruh Pasteurisasi Terhadap Kualitas Jus Jeruk Pacitan. Widya Teknik, Vol. 6, No. 2.
Vikram, V. B., Ramesh, M. N.dan Prapulla, S. G. 2005. Thermal Degradation Kinetics of Nutrients in Orange Juice Heated by Electromagnetic and Conventional Methods. Journal of Food Engineering Vol. 69.

Walpole, R. E. 1995. Pengantar Statistika. Gramedia Pustaka Utama. Jakarta.

Winarno, F.G. 2004. Kimia Pangan dan Gizi. Gramedia Pustaka Utama. Jakarta. 